\title{
INFANCIA CLANDESTINA OU A VONTADE DA FÉ ${ }^{1}$
}

INFANCIA CLANDESTINA OR THE WILL OF FAITH

Gonzalo Aguilar

Universidad de Buenos Aires

Buenos Aires

Argentina

\section{Resumo}

Este artigo discute como o filme Infancia clandestina (2012), de Benjamín Ávila, marca uma virada na representação cinematográfica da ditadura de 1976-1983, na Argentina. Por um lado, este filme se distancia de trabalhos de ficção como La historia oficial, de Luis Puenzo, regulado pelo arquivo e pelas evidências testemunhais e documentais disponíveis para o espectador para além do filme; por outro lado, a produção de Ávila não apenas inclui uma figura ausente nos filmes sobre o período feitos imediatamente após a ditadura, denominada guerrilheiro, mas também a desloca da verificação referencial demandada pelo testemunho e pela experiência autobiográfica da primeira pessoa para uma verificação que expressa - com a articulação imanente das unidades narrativas próprias da ficção - uma fábula de identidade comunitária sobre o passado histórico. Enquanto o mesmo poderia ser dito sobre documentários subjetivos mais recentes, centrados em um ponto de vista (aquele dos filhos de desaparecidos, que cresceram com uma biografia inventada) caracterizado pelo apagamento dos limites entre fato e ficçáo, como Los rubios, de Albertina Carri, ou $M$, de Nicolás Prividera, Infancia clandestina permanece isolado como um trabalho de ficção que, ao contrário desses filmes, abandona completamente o gênero documental. Finalmente, o artigo sugere que a alegorização do passado histórico em Infancia clandestina é tão poderoso que consegue subsumir numa narração ficcional o trauma da experiência dos anos da ditadura. O que se discute, portanto, não é a memória dessa narração, mas os modos e o valor dessa construção simbólica.

Palavras-chave: Infancia clandestina; Argentina; ditadura; guerrilha; filhos de desaparecidos; construção simbólica; documentário; ficção.

\section{Abstract}

This article argues that Benjamin Ávila's Infancia clandestina (2012) marks a turning point in the cinematic representation of the 1976-1983 dictatorship in Argentina. On the one hand, this film distances itself from works of fiction such as Luis Puenzo's La histo-

\section{Resumen}

Este artículo discute cómo Infancia clandestina (2012), de Benjamín Ávila, señala un viraje en la representación cinematográfica de la dictadura argentina de 19761983. Por un lado, el filme se distancia de trabajos de ficción como La historia oficial, de Luis Puenzo, regulado por el

1 Texto publicado em inglês em Journal of Romance Studies, issue 3, volume 13, Winter, 2013, pp.17-31, translation Glyn Fry (ISSN: 1473-3536). 
ria oficial, regulated by the archive and by testimonial and documentary evidence available to the viewer beyond the film. Conversely, Ávila's film not only includes a figure absent in films on the period made immediately after the dictatorship, namely the guerrillero, but it also shifts its discourse away from the referential verification demanded by testimony and from the autobiographical experience of the first person, to one that expresses - with the immanent articulation of its own fictional narrative units - a tale of community identity over the historical past. While the same could be said about more recent subjective documentary films centred on a point of view (that of the children of the disappeared who have grown up with an invented biography) characterized by a blurring of the boundaries between fact and fiction, such as Albertina Carri's Los rubios or Nicolás Prividera's $M$, Infancia clandestina stands alone as a work of fiction that, unlike these films, abandons the documentary genre altogether. Ultimately, the article suggests that the allegorisation of the historic past in Infancia clandestina is so powerful that it manages to subsume in a fictional narration the trauma of the experience of the years of dictatorship. What is at issue here is not the memory of the narrative, but rather the value of symbolic construction.

Keywords: Infancia clandestina; Argentina; dictatorship; guerrilla; children of the disappeared; symbolic construction; documentary genre; fiction. archivo y por las evidencias testimoniales y documentales disponibles para el espectador más allá del propio filme. Por otro lado, la producción de Ávila no sólo incluye una figura ausente en las películas sobre el período hechas inmediatamente después de la dictadura, denominada guerrillero, sino que la desplaza de la verificación referencial demandada por el testimonio y por la experiencia autobiográfica de la primera persona hacia una verificación que expresa - con la articulación inmanente de unidades narrativas propias de la ficción- una fábula de identidad comunitaria sobre el pasado histórico. Mientras lo mismo podría ser dicho sobre documentales subjetivos más recientes centrados en un punto de vista (el de los hijos de desaparecidos que crecieron con una biografía inventada) caracterizado por la borradura de los límites entre hecho y ficción, como Los rubios de Albertina Carri o $M$ de Nicolás Prividera, Infancia clandestina permanece aislado como trabajo de ficción que, al contrario de esos filmes, abandona completamente el género documental. Por último, el artículo sugiere que la alegorización del pasado histórico en Infancia clandestina es tan poderosa que logra subsumir en una narración ficcional el trauma de la experiencia de los años de dictadura. Lo que se discute, por lo tanto, no es la memoria de esa narración, sino los modos y el valor de dicha construcción simbólica.

Palabras clave: Infancia clandestina; Argentina; dictadura; guerrilla; hijos de desaparecidos; construcción simbólica; documental; ficción.

Infancia clandestina (2012), de Benjamín Ávila, representou uma novidade no corpus de filmes feitos por filhos de desaparecidos: diferentemente de Los rubios (2003), de Albertina Carri, M (2007), de Nicolás Prividera, Papálván (2004), de Inés Roqué, (h) historias cotidianas (2000) de Andrés 
Habegger, ou Nietos: identidad y memória (2004), do mesmo Ávila, Infancia clandestina é uma ficção. Além de quase não incluir material de arquivo ou passagens documentais, aspira, por sua forma, ser um filme narrativo mainstream de ficção, com um elenco estelar. ${ }^{2}$ Em outras palavras: embora os outros filmes documentais possuam procedimentos ficcionais ou zonas de ficcionalização, somente Infancia clandestina constitui uma ficção autônoma e abandona o gênero documental. A legenda "baseada em fatos reais" é uma amostra disso e uma exibição de que se narram fatos que aconteceram, mas são contados com todas as liberdades que uma história inventada concede.

A ficção em geral - escreve Jacques Rancière - não é a história bela ou a mentira vil que se opóem à realidade ou pretendem se fazer passar por tal. A primeira acepção de fingere não é "fingir", mas "forjar". A ficção é a construção, por meios artísticos, de um "sistema" de açóes representadas, de formas articuladas, de signos que respondem uns aos outros. ${ }^{3}$ (2005: 182)

O gesto já se fazia presente em Los rubios, que sustentava que não era possível compreender o passado sem a ficção, quer dizer, sem seus procedimentos de invenção, omissão e transformação. Mas também no filme de Carri desempenhava um papel central o fingimento, o fato de fazer-se passar pelo outro ou de recorrer a uma atriz para representar uma história real, o que conduzia a uma reflexão sobre as identidades e sua relação com a militância e a história. A diferença,em Infancia clandestina, é que a ficção - entendida como fingimento e construção - não é uma parte do filme, mas o afeta em sua totalidade: os dados testemunhais, para ingressar na narração, devem subordinar-se a seus mecanismos; por isso, a eficácia de Infancia clandestina não reside tanto em seu valor de testemunho como na construção narrativa

\footnotetext{
${ }^{2}$ Benjamín Ávila nasceu na Argentina, em 1972. Viveu parte de sua infância no exílio, com a mãe, Sara Zermoglio. Após o golpe de 1976, viajou com ela e o padrasto ao Brasil, depois ao México e, finalmente, a Cuba. No princípio de 1979, eles regressaram à Argentina, como parte da primeira contraofensiva montonera. Sara desapareceu em 13 de outubro desse mesmo ano. $\mathrm{O}$ irmão de Benjamín - que tinha, à época, 9 meses - foi criado por outra família e recuperou sua identidade no fim de 1984, sendo um dos primeiros netos restituídos pelas Abuelas de Plaza de Mayo. Diferentemente do que acontece no filme, depois do desaparecimento da mãe, Ávila foi criado pelo pai biológico, que estava divorciado dela. Infancia clandestina é o segundo longa-metragem de Ávila. O primeiro, Nietos: identidad y memoria, é de 2003.

Ficha técnica de Infancia clandestina. Direção: Benjamín Ávila. Roteiro: Benjamín Ávila e Marcelo Müller. Duração: 110 minutos. Elenco: Ernesto Alterio (tio Beto), Natalia Oreiro (Cristina/Charo), César Troncoso (Daniel/Horacio), Teo Gutiérrez Moreno (Juan/Ernesto), Victoria Paluka (María), Cristina Banegas (Amalia). Estreia: 20 de setembro de 2012.

${ }^{3}$ La ficción en general - escribe Jacques Rancière - no es la historia bella o la mentira vil que se oponen a la realidad o pretenden hacerse pasar por tal. La primera acepción de fingere no es "fingir" sino "forjar". La ficción es la construcción, por medios artísticos, de un "sistema" de acciones representadas, de formas ensambladas, de signos que se responden (RANCIĖRE, 2005: 182).
} 
deliberada do passado, que impóe suas próprias leis (as "formas articuladas", das quais fala Rancière).

Infancia clandestina conta a história de um menino de 12 anos de nome Juan (por Perón), que retorna à Argentina com sua família, como parte da contraofensiva montonera de 1979. Para poder entrar no país, ele recebe o nome falso de Ernesto (por Guevara). ${ }^{4}$ A família de Juan/Ernesto é formada pelos pais, Cristina/Charoe e Daniel/Horacio, e sua irmázinha de poucos meses de vida. Quase toda a história transcorre na casa-guarida da família, à qual se junta o tio Beto, e conta as mortes violentas dos pais e do tio em mãos da repressão. A narração adota o ponto de vista do menino e póe em cena dois processos paralelos: seu despertar amoroso ao lado da namorada, María, e a situação-limite que vive com a família. A história começa quando o protagonista recebe o nome de Ernesto e termina quando recupera o de Juan, ao ser deixado - na condição de único sobrevivente - por um grupo de tareas paramilitares na casa de sua avó Amalia, que tinha alertado a filha, Cristina, e o marido sobre o perigo que corriam, numa discussão fundamental para entender o sentido do filme.

$\mathrm{Na}$ sua escolha pela ficção, Infancia clandestina lembra aqueles filmes que, como La historia oficial, de Luis Puenzo, conseguiram condensar uma quantidade de sentidos políticos, percepçóes históricas e valoraçôes afetivas numa narração. A fidelidade testemunhal e o valor de verdade, centrais no gênero documental, cedem lugar a uma liberdade criativa que, embora não tão sujeita à prova referencial, é regulada de todo modo pelo arquivo e pela evidência documental com a qual conta o espectador para além do filme. Não obstante, a força do indício documental se faz presente em La historia oficial através das marchas das Madres de Plaza de Mayo, que irrompem no relato como a marca de um presente perturbador (as marchas são independentes da mise-en-scène ficcional, mas a avó de Plaza de Mayo que intervém na história é interpretada por uma atriz). ${ }^{5} \mathrm{O}$ passado recente estava sendo narrado pelas vítimas no mesmo momento em que se fazia o filme: por isso, embora não seja um documentário, La historia oficial não poderia ter sido contada sem os testemunhos da CONADEP. ${ }^{6}$ Esses testemunhos constituem um documento

\footnotetext{
${ }^{4}$ As contraofensivas montoneras ocorreram em 1979 e 1980 e consistiram na entrada de militantes do grupo Montoneros no país para infligir uma derrota final a uma ditadura que os dirigentes dessa agrupação consideravam débil e prestes a cair. $\mathrm{O}$ resultado foi contrário ao esperado e muitos desses militantes foram assassinados ou desapareceram, capturados pelo governo militar.

${ }^{5}$ Chela Ruiz (que interpreta Sara, uma avó que busca sua neta) tinha participado em mais de dez filmes e também era conhecida por suas atuaçóes na televisão.

6 CONADEP: Comisión Nacional sobre la Desaparición de Personas, constituída pelo presidente Raúl Alfonsín em dezembro de 1983. O filme supóe a circulação desses testemunhos que fizeram com que muitas pessoas tomassem consciência da natureza da repressão da ditadura. Se não tives-
} 
elidido, mas fortemente presente num momento em que a informação sobre os crimes da ditadura ia sendo desvelada pouco a pouco e o julgamento aos governos militares estava sendo levado adiante. A sentença, de fato, foi lida em dezembro de 1985, o mesmo ano de estreia do filme.

O contexto de Infancia clandestina é totalmente diverso e a quantidade de material documental acumulado durante os anos da democracia permite a Benjamín Ávila concentrar-se na história de uma família que participa da contraofensiva montonera sem a necessidade de muitas explicaçóes sobre a natureza da repressão. ${ }^{7}$ Se em La historia oficial sublinhava-se a figura da vítima inocente e o guerrilheiro não podia ser representado (embora fosse referido, de modo bastante crítico, pela personagem de Chunchuna Villafañe), em Infancia clandestina o guerrilheiro assume o centro da cena. Ele já havia começado a ser representado no cinema, depois de uma virtual supressão, em Montoneros, una historia (1994), de Andrés DiTella, e Cazadores de utopias (1996), de David Blaustein (que reabrem, no cinema, o testemunho dos que foram guerrilheiros nos anos 1970); mas, com Infancia clandestina, produz-se uma inflexão no ciclo. Cineastas como Benjamín Ávila se identificam com as políticas governamentais de direitos humanos e, o que nesse caso é mais importante, com essa visão do passado histórico, o que produz efeitos na construção narrativa do filme. ${ }^{8}$ Porque, embora a indiscernibilidade entre ficçáo e testemunho esteja presente tanto no cinema documental como no ficcional, e ainda que esses filmes se centrem num ponto de vista que justamente se caracteriza por nem sempre ter a capacidade de discerni-los (o ponto de vista das crianças, sobretudo dos filhos de desaparecidos que cresceram com una biografia inventada), Infancia clandestina, ao dotar a história da autonomia relativa da ficção, desloca seu discurso da constatação referencial que exige o testemunho e da experiência autobiográfica da primeira pessoa para a condensação - com a articulação imanente das unidades nar-

sem existido esses testemunhos, o filme teria sido obrigado a assumir um caráter de denúncia mais forte. No dilacerante relato de sua passagem pelos centros clandestinos de detenção, Ana (interpretada por Chunchuna Villafańe) diz ter dado seu testemunho junto à "comissão".

${ }^{7}$ Além de não fazer referências ao governo desse momento, há ainda o fato de que o relato deixa em aberto o futuro da irmázinha do protagonista, que o espectador pode supor devido aos casos de apropriação de crianças ocorridos durante a ditadura militar por parte das forças de repressão. Segundo o diretor, durante a rodagem, ele e Luis Puenzo (diretor de La historia oficial e produtor de Infancia clandestina) brincavam com o fato de que a bebê poderia ser Gaby, a menina apropriada de La historia oficial.

${ }^{8} \mathrm{O}$ crítico de cinema Quintín resenhou Infancia clandestina com o expressivo título de "Llegael cine kirchnerista" (<http://lalectoraprovisoria.wordpress.com/2012/09/30/llega-el-cine-kirchnerista/>, publicado em Perfil em 30/9/2012). A interpretação de Quintín se baseia, no entanto, mais na figura do autor que no que acontece no filme. Uma boa resposta pode ser lida numa nota de Julián Tonelli, "Sobre una crítica de Infancia clandestina", incluída em <http://cinemarama.wordpress. com/2012/10/20/sobre-una-critica-de-infancia-clandestina/> 
rativas próprias da ficção - de uma fábula de identidade comunitária sobre o passado histórico. Evidentemente, o mesmo pode ser dito de Los rubios ou de $M$, mas, nos filmes de Carri e Prividera, a forma fragmentária e de bricolage do documental se vincula com uma demanda de reconhecimento e de reparação endereçada ao Estado. Em $M$, o diretor percorre os escritórios das dependências estatais e increpa diferentes instituições; em Los rubios (com um estilo muito peculiar), a demanda se desloca para o debate estético-político e as críticas ao INCAA (Instituto Nacional de Cine y Artes Audiovisuales). Isso não ocorre em Infancia clandestina, que reduz a prova documental, prescinde da enunciação em presente e é construído a partir da não pessoa da ficção. Passamos das testemunhas às personagens, de um regime ético a um regime representativo, ${ }^{10}$ da narração fragmentária com efeitos do real ao relato acabado que produz verossimilhança e efeitos de realidade. Minha hipótese é que a construção simbólica que se produz sobre o passado histórico e a vontade de "mudar o mundo" dos militantes é tão poderosa que Infancia clandestina consegue subsumir numa narração ficcional o trauma da experiência dos anos da ditadura. O que se discute, portanto, não é a memória dessa narração, mas os modos e o valor dessa construção simbólica.

Se os documentários sobre desaparecidos tensionam permanentemente seus materiais entre um presente que lembra e um passado que se exibe mediante indícios, a ficção de Infancia clandestina não faz referências explícitas ao presente. Mais que um exercício de memória, é uma mise-en-narration: vela o presente da enunciação para promover no espectador uma identificação direta com o passado (o passado se torna presente). Não nos identificamos com alguém que lembra, mas com alguém que atua e cujo destino suspeitamos de antemão. Como a situação de conflito político já está resolvida no passado do presente do filme (a violência, antes que uma opção política dos militantes, seria uma reação à ditadura que é preciso combater com todos os meios possíveis), o espectador situa-se além das ideias e da memória, onde o que importa são os atos e as paixóes que movem os personagens. O caráter fragmentário, que nos outros filmes de filhos de desaparecidos era estrutural, centra-se aqui nos nomes dos personagens e sobretudo no do protagonista. $\mathrm{O}$

\footnotetext{
9 Sobre a terceira pessoa como "não pessoa", cf. Tercera persona. Politica de la vida y filosofía de lo impersonal, de Roberto Espósito (2009). Espósito se baseia nos estudos de Émile Benveniste que eu aplico, ironicamente, em relação ao dispositivo cinematográfico e à ideia de classificar uma série de filmes como "documentários em primeira pessoa".

${ }^{10}$ No ensaio "The aesthetic revolution and its outcomes (Emplotments of Autonomy and Heteronomy), Jacques Rancière propóe a existência de três regimes de arte: "um ético (vinculado com a verdade), outro representacional (a forma sobre a matéria, segundo normas intrínsecas) e, finalmente, um estético ("a fórmula-chave do regime estético da arte é que a arte é uma forma de vida autônoma") (RANCIÈRE, 2005: 137). Dos filmes de filhos de desaparecidos, Los rubios é o único que questiona o regime ético da arte com as ferramentas do regime estético.
} 
menino de Infancia clandestina tem cinco nomes ou apelidos: nasceu como Juan (por Perón), entra na Argentina como Ernesto (por Guevara), o pai o chama de Chango, os colegas de escola, Córdoba, e sua avó, Pollo. O Che é o modelo dessas metamorfoses de nome e de aspecto para passar à clandestinidade e Perón é o que sustenta a crença (“¡Perón o muerte!”, repetem os militantes em várias cerimônias). Junto ao instável nome do protagonista, há outra personagem que não tem nome: a irmázinha menor, de pouco menos de 1 ano de idade, que vive chorando enquanto seu irmão mais velho lhe diz "tranquila, tranquila". ${ }^{11}$ Entre a esquizofrenia e o anonimato, a narração desloca para o futuro uma conciliação de todos esses fragmentos, pelos quais se engaja a mãe (desaparecida), a menina desejada (María) e o menino (sobrevivente), o compromisso político e o prazer, as balas e o amendoim com chocolate, desde o olhar de uma criança que cresceu. Porque não é o menino de 1979 quem olha, mas o adulto que se pergunta sobre o que restou de sua experiência de clandestinidade:

[Fotos reais da mãe de Benjamín Ávila enquanto se ouve o diálogo em off] ERNESTO: Quero ficar com você para sempre.

MARÍA: Você promete?

ERNESTO: Com toda minha alma" [itálicos meus]. ${ }^{12}$

Justamente por prescindir do documental, é particularmente importante a apariçáo dos únicos dois materiais documentais históricos que o filme apresenta. Nos créditos finais, veem-se as fotos da mãe de Benjamín Ávila, procedimento habitual nos filmes de ficção baseados em fatos históricos (lembremos, para dar dois exemplos díspares e recentes, de Cidade de Deus, de Kátia Lund e Fernando Meirelles, e de Argo, de Ben Affleck). Com esse procedimento, reforça-se um núcleo de verdade da ficção e se conduz o espectador a refletir sobre a ficção sem perder de vista a premissa de que houve fatos similares aos narrados no filme. O outro material é o noticiário televisivo de ATC (Argentina Televisión Color) 60 minutos - conhecido pelo oficialismo extremo durante a ditadura-,que termina com uma foto do ator César Troncoso, que desempenha o papel do pai. A passagem define a forma de Infancia clandestina: o documental se subordina ao ficcional e isso significa que os indícios com frequência restos traumáticos ameaçadores - conseguem ser absorvidos pela simbolização. Em outras palavras: a simbolização acaba subordinando o real e o indício do cinema é suprimido em favor do caráter simbólico dos desenhos. Por isso, não é casual que os momentos-limite, como as cenas de

${ }^{11}$ Seu nome é Vicky, mas é dito somente uma vez, de passagem, e não se sabe se é seu nome verdadeiro ou falso.

${ }^{12}$ Ernesto: "Quiero estar con vos para siempre”. María: “¿Me loprometés?”. Ernesto: “Con toda mi alma”. 
violência, sejam representados mediante desenhos, como se se tratasse de um comic (com exceção da cena, muito complexa, na qual o menino é ameaçado por um repressor, como se esse momento não admitisse reelaboraçóes ulteriores, como se o próprio diretor necessitasse pôr o corpo).

A violência é o mais real, o mais difícil de ser apresentado como tendo uma finalidade justificada e, portanto, de ser simbolizado. Por isso, os desenhos (ficção da ficção) lhe atribuem sentido através dessa máquina simbólica que constrói o olhar de Ávila, apoiado - como se verá posteriormente - na memória do passado que foi construída nos últimos anos. Que dizem esses desenhos? Que o calvário de Ernesto é comparável ao de Che Guevara e que ele deve despedir-se de María, sua iniciação amorosa frustrada. Ou seja: que deve adiar sua iniciação amorosa para enfrentar sua orfandade política (na linguagem simbólica do filme: que o amendoim com chocolate é muito gostoso, mas que agora é tempo de balas), ${ }^{13}$ No momento em que são descobertos pelas forças repressivas, os desenhos de Ernesto se misturam com os da detenção e posterior morte de Che Guevara na Bolívia. Os últimos desenhos mostram María com um guarda-chuva, sob a chuva - no início, a imagem parece ser a da mãe -, que se afasta para sempre do olhar do protagonista. A primeira solução vincula todos os elementos que têm a ver com a crença na revoluçáo, o mandato do pai ("você vai fazer algo parecido ao que fez o Che”, diz a Ernesto no início do filme), e que vão da presença mítica de Cuba à promessa final feita à mãe, à qual Ernesto garante que será fiel "para sempre". A mesma promessa que tinha sido feita a María ("quero ficar com você para sempre”), agora é feita à mãe. O protagonista - como todo herói - não somente ambiciona a eternidade, mas, neste caso, vive uma particular disputa entre a namorada e a mãe, que, finalmente, é vencida pela mãe (em várias ocasióes, ela se burla da relação com María e a proíbe por razôes políticas, embora os ciúmes sejam evidentes). A disputa atinge o ápice no momento em que Ernesto, angustiado por ter ficado sabendo que o pai fora descoberto (é o que vemos na televisão), adormece na cama e, quando a mãe entra no quarto - com um homem detrás -, aponta uma arma para ela. Ernesto, ao reconhecê-la, não dispara, e ambos se fusionam num abraço na cama. A cena remete a outra mais idílica, na qual Cristina, deitada na grama com seu filho,

\footnotetext{
${ }^{13}$ Aqui se vê (e se explica) um interessante deslocamento da ficção: na história de Benjamín Ávila, ele vai viver com seu pai (a mãe tinha se divorciado e casado novamente com um militante), na ficção, vai morar com sua avó. A figura do pai não se desdobra porque a articulação ficcional exige que seja mantida a economia triangular e edípica que sustenta a narraçáo. Também muda a idade do menino: Ávila tinha 7 anos, Juan/Ernesto se aproxima mais da puberdade (tem 12 anos).
} 
diz, enquanto o abraça: "você gosta de uma menina... olha que eu mato essa pestinha... você é meu, meu, meu”. ${ }^{14}$

Em que consiste a disputa? Na hesitação do herói entre seguir o caminho dos pais (a militância política, as balas) e o desejo amoroso (o namoro com María, o amendoim com chocolate). A oposição é forte, mas há vários momentos nos quais se tenta uma conciliação: não somente colocam-se balas nas caixinhas de amendoim com chocolate (o plano do amendoim com chocolate fracassou, diz o pai), ${ }^{15}$ como existe o personagem do tio Beto, que faz uma defesa calorosa do prazer aqui e agora. Beto prepara a festa, leva a mãe de Cristina até a casa e demonstra, finalmente, contra os insultos de Daniel/ Horacio, que também "tiene huevos". Infancia clandestina narrativiza, portanto, um conflito central da militância desses anos, entre os prazeres da vida cotidiana e a entrega a uma militância que podia conduzir à morte.

\section{Olhos vendados que olham}

Uma das primeiras conclusóes derivadas da história que o filme narra é que Amalia, a avó, finalmente tinha razão. A casa na qual viviam os protagonistas era uma arapuca, havia gente sendo descoberta por toda parte e o destino que esperava Cristina, Horacio e Beto era a morte. Os pais e o tio do menino negam essa interpretação. Mais ainda, Beto responde: "Nós estamos ótimos, as crianças estão ótimas, temos uma vida normal". ${ }^{16}$ Somente quando chega à casa da avó o menino consegue recuperar sua identidade ("Sou Juan”) e quebrar, dessa forma, a fantasia de seu nome clandestino. Segundo esta interpretação, que adota o ponto de vista da avó, eles são uns negadores e a contraofensiva montonera uma loucura ("Náo diga que isto é uma loucura, porque não é", ${ }^{17}$ diz o pai de Juan à sogra, confirmando o fato pela negativa). A noção mais adequada para descrever essa situação é a noção de delírio: quando Ernesto, rodeado de espelhos que fragmentam sua identidade, propóe a María fugir para o Brasil com o dinheiro subtraído aos pais (e que era destinado à luta política), o grau de isolamento e de negação do menino exibe o caráter transtornado de toda a aventura. A infância clandestina o faz acredi-

\footnotetext{
14 “Te gusta una compańerita... mirá que la mato a esa chinita de porquería... mío, mío, mío”. A cena é imediatamente posterior à de Ernesto sonhando com um beijo de María e fazendo xixi na cama, do lado do tio Beto (que o inicia primeiro nos segredos do amor e depois na coragem política).

15 "lo del maní con chocolate fracasó".

16 "Nosotros estamos perfectos, los chicos están perfectos, llevamos una vida normal".

17 "No digas que esto es una locura, porque no lo es".
} 
tar que as fantasias podem se cumprir. ${ }^{18}$ "Não é isso o que você quer?", ${ }^{19}$ diz Ernesto, referindo-se ao fato de que, no carro desmantelado, María expressara seu desejo de ir ao Brasil. Mas ela sabe diferenciar entre a vida cotidiana e as fantasias, algo que Ernesto, imerso na fantasia clandestina da família, não consegue fazer. A clandestinidade enceguece em relação ao real.

Mas esse argumento, embora possua um valor de verdade, é insuficiente. Diante do senso comum de Amalia e do delírio da contraofensiva montonera, Infancia clandestina se pergunta como olhar esse passado histórico. Para fazê-lo, recorre a um dos símbolos da repressão militar e dos filmes sobre a ditadura: refiro-me aos olhos vendados. Os olhos vendados, que foram um símbolo da situação de penúria à qual eram submetidas as vítimas (desde La noche de los lápices (1986), de Héctor Olivera, até Garage Olimpo (1999), de Marco Bechis), são usados aqui nos companheiros ou conhecidos: são os próprios militantes os que aparecem vendados, embora, desta vez, com o próprio consentimento. ${ }^{20} \mathrm{~A}$ imagem não iria além de uma representação das medidas de segurança das organizações guerrilheiras se a ficção não a modulasse e continuasse noutras cenas. Os meninos, também de olhos vendados, brincam de cabra cega no acampamento e a canção 'infantil' composta por Benjamín Ávila e Pedro Onetto para o filme se refere à dificuldade de saber olhar. "Não enxergo... não posso", cantam os meninos e se perguntam: "será que estou cego?". Pergunta à qual todos respondem: "você precisa lentes de gente decente". ${ }^{21}$

Mas, quais são as lentes/óculos que é preciso usar para interpretar a história? Deve-se recorrer àquilo que falta aos personagens - "lentes de gente decente" - ou deve-se optar por outras? Na sequência de desenhos animados

\footnotetext{
${ }^{18}$ A fantasia de Ernesto, vinculada a sua proposta de viagem ao Brasil com María, acaba no que lhe sobra da cena do interrogatório: uma foto com ela no carro. Há, também, outro elemento a ser levado em conta: nas sequências de desenhos animados predominam as cores escuras e o vermelho do sangue, salvo na cena de María dançando com uma fita de cor amarela forte, cor que, no filme, vincula-se à esperança. Quando Ernesto chega à casa da avó, na noite azul e escura, as luzes que se acendem também são amarelas. Trata-se da ideia de que a luta pela esperança de encontrar seus pais e sua irmá apenas começa?

19 “¿No es esto lo que querías?”.

${ }^{20}$ Ver o que afirma Valeria Manzano em seu ensaio “Garage Olimpo o cómo proyectar el pasado sobre el presente (y viceversa)": "Embora, enquanto objeto, a venda constitua parte do acervo comum das representaçōes em torno das experiências concentracionárias, considero que, em Garage Olimpo, esta devém, metonimicamente, a própria figura do desaparecido e do espaço social que (não) o contém" " $\mathrm{Si}$ bien, en tanto objeto, la venda constituye parte del acervo común de las representaciones en torno a las experiencias concentracionarias, sugeriré que en Garage Olimpo esta deviene, metonímicamente, la figura misma del desaparecido y del espacio social que (no) lo contiene") (em FELD, 2009: 158). A imagem de um rosto com os olhos vendados está presente nos cartazes de $\mathrm{La}$ noche de los lápices e de Garage Olimpo, e também no cartaz norte-americano de Infancia clandestina. ${ }^{21}$ Letra: Benjamin Ávila / Música: Pedro Onetto. A letra da cançấo inteira gira em torno do tema do olhar.
} 
em que sonha com a morte de seu tio Beto, Ernesto termina com os óculos do tio em seu rosto. Não são lentes/óculos de gente decente; Ernesto já os tinha experimentado no início do filme, ao imitar Adolfo Mena, o personagem careca e de óculos assumido por Che Guevara para entrar na Bolívia (no início, mostram-se suas metamorfoses através de desenhos de Ernesto). Visto "com lentes de gente decente", o filme é um delírio, mas, desde outro ponto de vista, os protagonistas são heróis que não cedem em seu desejo, que não claudicam de sua fé. Chamar-se Juan, mas também Ernesto. Vendar-se os olhos é a passagem de uma realidade a outra, mais próxima do desejo, na qual o desejo sempre está prestes a se realizar. ${ }^{22}$ É preciso adquirir óculos (não os da gente decente) para ver o futuro sem perder a fé.

Os olhos vendados, então, neste filme, não são a privação da liberdade, mas um possível acesso a ela. É isso que o herói faz: nega - ainda que seja num ato de onipotência ou de loucura - os obstáculos reais, para prometer outro mundo, no qual não seja necessário vendar-se os olhos. Esse outro mundo prometido não é apresentado no filme (a ditadura acaba derrotando os personagens), mas é sempre iminente. A iminência da realização do desejo percorre toda a história de Ernesto, embora a consumação nunca se produza. Não há revolução nem relação amorosa. Quando Ernesto está prestes a beijar María, aparece o irmão dela e tira uma foto de ambos, interrompendo o ato. Toda a história tem algo dessa iminência: inclusive a inesperada festa de aniversário de Ernesto, no dia 7 de outubro, um dia antes do nascimento de Perón e dois dias antes da morte de Che Guevara. Esse fracasso do desejo fala (como se vê claramente no relato de Daniel/Horacio sobre seu irmão Beto) da necessidade de se sustentar o desejo, de "conservar a fé", como reza a dedicatória que encerra o filme. Essa iminência é própria da escatologia revolucionária $^{23}$ e a pergunta que surge da derrota é: o que sobra, segundo Infancia clandestina, de toda essa experiência?

\section{Paixões políticas e poder de simbolização}

É possível ler Infancia clandestina a partir das três perspectivas que foram aplicadas à análise da guerrilha dos anos 1970: a político-estratégica, a avaliação do projeto político e a ética dos afetos e da vontade. A primeira delas cen-

\footnotetext{
${ }^{22}$ As mençôes aos óculos se disseminam pelo filme. Por exemplo, quando Ernesto pergunta à mãe do que ela gostava no pai, ela diz: "desses óculos que ele usava!" (o pai não deixa de usar os óculos durante todo o filme).

${ }^{23}$ Segundo Hugo Vezetti, "Este sentido de iminência de um acontecimento, que se revelaria em diversos signos, edifica uma verdadeira escatologia revolucionária" (VEZETTI, 2009: 166).("Este sentido de inminencia de un acontecimiento, que se revelaría en diversos signos, edifica una verdadera escatología revolucionaria").
} 
trou-se principalmente na condução das organizaçôes, sobretudo em algumas ações, entre as quais a mais criticada foi a contraofensiva montonera de 1979, que constitui, justamente, o tema do filme. Em seu livro Política y/o violência: una aproximación de laguerrilla de los años 70, Pilar Calveiro assinalou os aspectos mais negativos da guerrilha argentina dessa época: o pragmatismo que empobreceu a discussão teórica, a falta de inserção nos setores populares, a prevalência da lógica revolucionária sobre o sentido de "realidade", a militarização do político e a falta de debate interno e do reconhecimento da dissensão dentro das organizaçôes (as observaçôes aplicam-se tanto a Montoneros como ao ERP - Ejército Revolucionario del Pueblo). Para Calveiro, "a derrota de Montoneros [...] não se deveu a um excesso do político, mas a sua carência" (2005: 23). Desde que passou à clandestinidade, durante o governo democrático, a organização desestimou todas as vias políticas (quer dizer, de negociação e de consenso) para entregar-se à guerra de guerrilhas contra um inimigo que era considerado em termos absolutos. ${ }^{24}$

As outras duas chaves interpretativas são complementares à crítica do fracasso político-militar, não obstante possuam valor oposto: admitem que, embora as açôes pudessem ser equivocadas, não o foram nem a ideologia que as impulsionavam nem o desejo e a vontade que as moviam. A análise, nesses dois casos, centra-se mais nos militantes que nos dirigentes e hesita entre as considerações afetivas e as ideológicas (por isso, alimentam-se mutuamente e podem relacionar-se entre si). O conceito-chave é o de vontade que, desde a publicação de La voluntad: una historia de lamilitancia argentina, de Martín Caparrós e Eduardo Anguita, em 1997, vem sendo aplicado à militância em geral e também às organizaçóes guerrilheiras. Se o tópico tem sido muito efetivo no campo dos afetos (a vontade inquebrantável dos militantes que não cederam sequer diante da morte é algo que não costuma ser questionado), em termos de avaliação política desembocou na defesa de uma ideologia difusa, segundo a qual "queriam um mundo melhor", lugar-comum que lança mão de uma das palavras mágicas na consideração daqueles anos: "melhor", "os melhores". Resulta difícil manter uma doutrina como a de Montoneros na atualidade, por sua apelação irrenunciável à violência e, num nível mais concreto, sustentar a noçáo de vontade para um movimento como o peronista, cuja categoria central foi a de lealdade, que se opôe, regula ou diretamente suprime a vontade. Quando a lealdade é o valor principal (e a única consigna política explícita no filme é “Perón o muerte!”), a vontade deve subme-

\footnotetext{
${ }^{24}$ Sobre o tema do inimigo absoluto, isto é, quando se quebra a lógica política amigo-inimigo, cf. Teoría del partisano, de Carl Schmitt, (2005: 112), é importante assinalar que a suspensão da lógica política por parte de Montoneros foi concebida para dar lugar a um enfrentamento militar que somente teria fim com a vitória ou a derrota.
} 
ter-se ao desejo e à vontade do outro. Suprime-se a pluralidade de pontos de vista e a traição surge como corolário natural. Por isso, esta leitura, ao passo que sustenta ideias difusas (embora seja preciso não desmerecer, em Infancia clandestina, a defesa enfática da experiência cubana), ${ }^{25}$ explora a retórica dos afetos e as paixóes puras que impulsionavam os que empreenderam a "contraofensiva montonera".

Tais perspectivas são tratadas cinematograficamente, em Infancia clandestina, através de três aspectos: a crítica da personagem da avó Amalia, a defesa da coragem e o heroísmo dos militantes da guerrilha montonera e a exclusão da figura do traidor. Nos três casos, a defesa da fé revolucionária como algo puro e que está a caminho de realizar-se tem um poder de simbolização táo forte que consegue subsumir o trauma da violência e da derrota.

A personagem de Amalia adverte a filha e a família desta sobre o perigo que correm e, como demonstra o desenvolvimento posterior do relato, tinha razão. O filme não nega isso nem deixa de exibir todos os defeitos que se atribuíram à organização Montoneros (as afirmações de Calveiro podem comprovar-se em várias cenas do filme). Mas, se a visão de Amalia falha, é porque, para o filme, a crítica política ao agir das organizaçóes guerrilheiras é secundária. Não há discussôes ideológicas ou doutrinárias no filme, nem referências muito precisas ao que está ocorrendo (exceto Belgrano, Perón e Che Guevara, não são nomeados personagens históricos e, menos ainda, personagens vivos). Quer dizer que, embora Amalia tenha razão, há uma dimensão que seu discurso não afeta: a da fé na revolução, a do que deve conservarse "para sempre", o que deve transmitir-se de uma geração a outra. Mais que tratar de política, Infancia clandestina trata das paixóes que a política desencadeia e que a precedem. Por isso, é menos importante o fato de Amalia ter razão que ofato dela ter medo. "Você é uma medrosa, sempre foi, papai tinha razão", ${ }^{26}$ diz a filha. É menos importante que a mãe seja sensata (ou "decente") que sua renúncia à esperança. Amalia não tem nenhuma fé que conservar.

As duas paixóes que mobilizam a política (medo e esperança) são as que estão em jogo na aventura da família. ${ }^{27} \mathrm{O}$ medo, sabe-se desde Maquiavel

\footnotetext{
${ }^{25} \mathrm{O}$ tema da projeção da revolução cubana na atualidade (porque se trata de um filme de 2012, ainda entusiasta em relaçấo a esse projeto) é demasiado complexo para ser tratado aqui. De todo modo, coincido com o exposto por Claudia Hilb (2013: 45ss.).

26 "Sos una cagona, siempre lo fuiste, papá tenía razón”.

${ }^{27}$ No livro Geometría de las pasiones, Remo Bodei faz uma análise das paixões políticas, que não necessariamente define a esperança como positiva e o medo como negativo. Embora seja essa a tendência predominante, a esperança, com frequência, "subestima os obstáculos" (1995: 473) e o medo pode vir a ser estilizado - quanto a isso, Bodei segue Hobbes - numa paixão universal calculista que se diferencia do terror panicus, no qual prima a desesperação e "cada um segue casualmente o exemplo do primeiro que pareça agir com base em algum critério" (1995: 85). Amalia,
} 
e Montesquieu, é a matéria com a qual se modelam os despotismos. Com gente como Amalia, a ditadura duraria para siempre. Ao invés disso, a família de Cristina/Charo e Daniel/Horacio está disposta a dar a vida para mudar o estado das coisas, embora isso lhes custe a morte. A vontade (heroica ou delirante) a partir de uma fé (daí sua pureza moral) é o sustento último da história. Ao situar a visão sobre o passado no terreno da vontade, Infancia clandestina instaura uma identificação com os personagens, associada à valentia e à audácia (o que no filme se expressa como "tener huevos"). ${ }^{28}$ Por isso, o eixo do filme situa-se na ação dos personagens e não na organização à qual pertencem, da qual pouco se diz e cujos aspectos mais controvertidos são elididos. O que mais chama a atenção é o comprimido de cianureto que, como se sabe, os guerrilheiros levavam para não serem capturados com vida pela ditadura. Os militantes sabiam que a tortura os esperava, mas também sabiam que a organização Montoneros não aceitava a delação e a julgava duramente mesmo que tivesse sido feita sob tortura. Em outras organizaçóes, como a Frente de Liberação da Argélia, concedia-se aos prisioneiros um tempo limitado para que os esconderijos pudessem ser removidos e os militantes advertidos. Transcorrido esse período de tempo, o detento podia "cantar" (confessar). Impulsionados pela formação cristã e pela idealização dos mártires - como se denominava os mortos pela repressão -, os dirigentes montoneros não admitiam estabelecer um termo temporal à relação entre a tortura e a delação. ${ }^{29}$ Por isso, a decisão dos comprimidos de cianureto lhes parecia razoável e militarmente preferível: era melhor perder um soldado que ficar com um delator potencial. ${ }^{30} \mathrm{Em}$ Infancia clandestina, o comprimido de cianureto não aparece, mas a morte do tio Beto vincula-se a esse fato porque ele prefere morrer a ser detido com vida. Segundo narra o personagem de Horacio, que foi tes-

segundo sua filha, tem "medo" e "pânico"; o pai reconhece que tem medo ("todos temos medo" $\mathrm{diz})$, mas o supera com sua entrega e valor.

${ }^{28}$ Toda a discussão entre compromisso/engajamento e prazer que mantém Horacio e Beto gira em torno aos genitais masculinos como reservatório de heroísmo ("la granpija argentina", "los tengo bien puestos"), embora, em excesso, a masculinidade possa ser prejudicial: "Sos um pelotudo". Helios Prieto, conforme conta Ana Longoni (2007: 163), fala de "debate testicular": as açôes da guerrilha "tinham se reduzido a um debate testicular segundo o qual se tratava exclusivamente de saber quiénes tenian h. y quiénes no".

${ }^{29}$ Uma ideia similar existia na agrupação de esquerda ERP (Ejército Revolucionario del Pueblo), de formação marxista, motivo pelo qual seria preciso matizar o componente cristáo.

${ }^{30}$ Sobre o caráter problemático dos sobreviventes, aos que se considerou frequentemente como traidores, ver o livro de Ana Longoni (2007: 181): “Trata-se de uma forma de entender a política que se situa no registro do sacrifício: a paixão política parece incluir um sentido da ética que não permite regressar sobre os próprios passos nem resguardar-se nem abandonar, sem ser considerado um traidor". "Se trata de una forma de entender la política que se instala en el registro de lo sacrificial: la pasión política parece incluir un sentido de la ética que no permite regresar tras los propios pasos ni resguardarse ni abandonar, sin ser considerado un traidor". 
temunha direta da detenção de seu irmão, Beto gritou que não iam levá-lo com vida, pegou uma granada, abraçou um policial e se jogou com ele dentro do carro. O carro deve ter ficado bastante parecido ao carro que serve como lugar de encontro amoroso entre Ernesto e María, e o policial... bem, o policial, enquanto inimigo, não tem direito à vida. Beto demonstrou que "tenía huevos"e que sequer a vida de outro ser humano ia deter seu desejo: morrer pela revolução. Se o carro destroçado é o lugar do desejo, a fé de Beto dota-o de sentido, aplaca sua presença brutal e seu caráter destrutivo. No relato do herói há destruição, mas essa destruição acaba sendo redimida pelos valores que o personagem, nesse caso, Beto, encarna. A representaçáo heroica dada a ver mediante os desenhos provê a chave do filme: o poder de simbolização é tão intenso que os indícios do real são subsumidos e até mesmo suprimidos na rememoração do passado. Por isso, Infancia clandestina pode abandonar o documental e até aceder à imagem no registro indicial por excelência: o desenho animado. Não se deve subestimar semelhante poder de simbolização, visto que não é exclusivo deste filme, mas articula-se com diversas práticas artísticas e culturais e com as políticas de um Estado que busca reforçar a memória social do passado. Por isso, é importante assinalar que essa simbolização se realiza às custas de equiparar os tempos históricos (o passado, o presente, o futuro) a partir de categorias morais e suprimindo a dimensão estritamente política. Afirma-se que se trata de uma juventude maravilhosa (como na idílica imagem na qual os militantes interpretam "Sueños de juventud", de Enrique Santos Discépolo), porém elide-se a opção pela violência não apenas como resistência à ditadura (tese de Ávila), ${ }^{31}$ mas como ferramenta política privilegiada para a resolução de conflitos. O carro destroçado do real é redimido pela fé dos personagens; o dano e o trauma pela cegueira visionária da fé.

A mise-en-scène idílica surge em vários momentos do filme: quando Ernesto vê María dançar pela primeira vez, nos desenhos e nas 'fotos' familiares, no momento em que gravam a fita desde Cuba e, acima de tudo, no

\footnotetext{
${ }^{31}$ Numa resposta ao jornal espanhol El País, em que se comparava Montoneros com a ETA, a propósito de seu último filme, Benjamín Ávila escreveu que: "Montoneros se formou na ditadura (1970) e foi aniquilado pela última ditadura. Nunca exerceu isso [a violência] em democracia. Posso acrescentar, ademais, que nenhum dos sobreviventes pensaria hoje, nem pensou durante a democracia, em levantar as armas para construir o país. A defesa da democracia e os ideais foi o motivo de sua luta" "Montoneros se formó em dictadura (1970) y fue aniquilado por la última dictadura. Nunca ejerció esto endemocracia. Puedo agregar además que nadie de los sobrevivientes hoy en día se le ocurriría, ni se le ocurrió en democracia, levantar las armas para construir el pais. La defensa de la democracia y las ideas fue el motivo de su lucha"). Entretanto, não há nenhum documento histórico que corrobore semelhante afirmação: a palavra "democracia" não formava parte do léxico politico de Montoneros e tinha um valor negativo associado à democracia parlamentarista burguesa. Isso não obsta que defendessem o governo democrático de Cámpora e, depois, de Perón, mas não por ser democrático, porém porque o consideravam revolucionário. De fato, autodeclararam-se "clandestinos" justamente durante o governo democrático de Isabel Perón, no ano de 1975.
} 
churrasco que os companheiros montoneros compartilham enquanto se ouve a canção "Sueños de juventud". Os militantes chegam e vão embora com os olhos vendados, mas, no ínterim, veem-se cenas de amor, amizade, companheirismo, risos, lágrimas, sexo e de descoberta do mundo adulto por parte de Ernesto. Um mundo idílico de luminosidade diáfana e cores claras que contrastam com as cenas de violência (escuras e realizadas com animação), que representam e simultaneamente elidem (o primeiro ataque armado à família ao entrar na casa, a morte de Beto, a captura final de Ernesto).

Se, por sua capacidade de condensação e sua função catártica, Infancia clandestina lembra La historia oficial, de Luis Puenzo, ambos se opóem quanto à representação dos personagens. La historia oficial evitava mostrar o militante guerrilheiro que havia desaparecido, o esposo de Ana. Os personagens o mencionavam, mas ele sempre permanecia nos limites da história como um fantasma: era preciso invocá-lo, mas náo deixá-lo falar. Infancia clandestina centra-se justamente num grupo guerrilheiro e o exterior se mostra de uma forma enviesada, através do olhar de um menino. A figura aludida, mas simultaneamente não representada, o fantasma da ficção, é, nesse caso, o traidor ou o delator, que seria "el Gallego", personagem que não aparece mas é mencionado pelo pai de Ernesto, a propósito de um encontro..."cita cantada”. ${ }^{32}$ A ficção, embora reconheça sua existência, não pode incluir um personagem traidor porque - desde esta visão da história - questionaria o heroísmo, a abnegação e a pureza dos militantes. Não se pode mostrar essa vontade curvada, ainda que sob tortura. O ensinamento que tio Beto, depois de morto, deixa ao sobrinho, é muito claro: "a única coisa que tenho a dizer é que você não traia a si mesmo".

A impossibilidade de representar narrativamente o ponto de vista dos guerrilheiros foi vinculada, na volta à democracia, à construção da "vítima inocente". Foi essa demanda narrativa ("conte sua história como vítima, mas não reivindique seu passado") $)^{33}$ que gerou um efeito de clausura sobre o relato dos anos 1970 e uma interdição tácita sobre a discussão do que foi feito pela guerrilha, que somente começaria a ser resgatada muitos anos depois (no cinema, com os já citados Montoneros, una historia, de Andrés Di Tella, e Cazadores de utopia, de David Blaustein, de 1994 e 1995, respectivamente). Mas, se no retorno à democracia existiu essa interdição, a mudança foi gradativa e se chegou no discurso oficial, ao guerrilheiro apaixonado e inocente. ${ }^{34} \mathrm{~A}$ visão

\footnotetext{
32 Dessa forma eram chamados os encontros de militantes das agrupaçóes armadas que tinham sido delatados por companheiros capturados ou descobertos pelas forças repressivas.

33 "contá tu historia como víctima pero no reivindiques tu pasado".

${ }^{34}$ Não é possível falar de culpabilidade, ao menos do ponto de vista jurídico, já que as vítimas não tiveram a possibilidade de aceder a um julgamento, direito universal que lhes correspondia. Mas,
} 
de Infancia clandestina, oposta nesse sentido à de La historia oficial, é muito mais unilateral. Segundo a legenda com que se inicia o filme, a violência foi produto de "grupos parapolicias" ("1974. Após a morte do general Perón, grupos parapoliciais desencadearam a violência na Argentina"). ${ }^{35}$ Dessa maneira, Infancia clandestina amarra, mediante uma história comovente e bem narrada, todos os fios da visão sobre os anos 1970 que se construiu nos últimos anos desde o Estado: heroicidade, juventude, obliteração da ideologia em favor de princípios abstratos, glorificação da vontade militante.

Ao relatar a morte de Beto, o pai de Ernesto faz um esclarecimento muito importante: "para Beto, a felicidade não é um sorriso, mas uma crença, uma fé". Será a mesma fé da dedicatória que encerra o filme, "dedicado a todos os que conservaram a fé”? É esse o olhar infantil que Ávila constrói com seu relato. Não se trata da menina que se situa numa zona de ignorância e é vítima da ditadura de La historia oficial; tampouco dos meninos de Los rubios, que ficam em meio a um fogo cruzado e não têm capacidade para ler o que ocorre. ${ }^{36} \mathrm{O}$ menino de Infancia clandestinaé capaz de cumplicidade e até de exercer uma transgressão que afeta à própria família. É um menino que é vítima dos atos de seus progenitores (o filme não anula a crítica política à contraofensivamontonera, mas, inclusive, a reforça), porém que fica com o tesouro de uma experiência mais profunda: a promessa de ser fiel a essa esperança "para sempre".

Tradução Miriam V. Garate Revisão Natalia Christofoletti Barenha

em antagonismo à visão reivindicativa daqueles anos, que os torna inocentes (jogando a culpabilidade nos quadros dirigentes), cresce também a bibliografia que fala da responsabilidade desses grupos na violência do período. Quer dizer, não é uma questão de culpabilidade ou inocência, mas de responsabilidade.

35 “1974. Tras la muerte del General Perón, grupos parapoliciales desencadenaron la violencia en la Argentina”.

${ }^{36}$ Em seu ensaio "Estrategias para crearel mundo: la década del setenta enel cine documental de los dos mil", Lorena Verzero observa que havia, "por um lado, a necessidade de ter filhos para assegurar a continuidade da revolução e, por outro, de fazer a revolução para os filhos; criar um mundo diferente para as gerações posteriores e, ao mesmo tempo, educá-las na revolução" (FELD, 2009: 210). "Por un lado, la necesidad de tener hijos para asegurar la continuidad de la revolución y, por otro, de hacer la revolución para los hijos; crear un mundo diferente para las generaciones posteriores y, al mismo tiempo, educarlas en la revolución." 


\section{Referências bibliográficas}

BODEI, Remo. Geometría de las pasiones: miedo, esperanza, felicidad: filosofía y uso político. México: Fondo de Cultura Económica, 1995.

CALVEIRO, Pilar. Política y/o violencia. Una aproximación de la guerrilla de los años 70. Buenos Aires: Norma, 2005.

CAPARRÓS, Martín; ANGUITA, Eduardo. La voluntad. Una historia de la militancia argentina. Buenos Aires: Norma, 1997.

ESPOSITO, Roberto. Tercera persona. Politica de la vida y filosofía de lo impersonal. Buenos Aires: Amorrortu, 2009.

HILB, Claudia. Usos del pasado. Buenos Aires: Siglo XXI, 2013.

LONGONI, Ana. Traiciones. La figura del traidor en los relatos acerca de los sobrevivientes de la represión. Buenos Aires: Norma, 2007.

MANZANO, Valeria. "Garage Olimpo o cómo proyectar el pasado sobre el presente (y viceversa)”. In: FELD, Claudia; STITES MOR, Jessica Stites Mor (comp.). El pasado que miramos (Memoria e imagen ante la historia reciente). Prólogo de Andreas Huyssen. Buenos Aires: Paidós, 2009.

RANCIÈRE, Jacques. "The aesthetic revolution and its outcomes (Emplotments of Autonomy and Heternomy)". New Left Review, 14, março-abril, 2002.

La fábula cinematográfica: reflexiones sobre la ficción en el cine. Barcelona: Paidós, 2005.

SCHMITT, Carl. Teoría del partisano. Buenos Aires: Struhart\& Cía., 2005.

VERZERO, Lorena. "Estrategias para crear el mundo: la década del setenta en el cine documental de los dos mil”. In: FELD, Claudia; STITES MOR, Jessica Stites Mor (comp.). El pasado que miramos (Memoria e imagen ante la historia reciente). Prólogo de Andreas Huyssen. Buenos Aires: Paidós, 2009.

VEZZETTI, Hugo. Sobre la violencia revolucionaria: memorias y olvidos. Buenos Aires: Siglo XXI, 2009.

Gonzalo Aguilar é professor de Literatura Brasileira na Universidad de Buenos Aires, pesquisador do Consejo Nacional de Investigaciones Científicas y Técnicas e diretor da Maestría de Literaturas de América Latina da Universidad Nacional de San Martín. Principais publicaçóes recentes: A poesia concreta: as vanguardas na encruzilhada modernista (2005); Episodios cosmopolitas en la cultura argentina (2009). 